\title{
Transforming an Industrial District into a High-Tech Cluster: Assessing the Cosmetics Valley's Readiness and Benefits
}

\author{
Daniel D. Bretonès (corresponding author) \\ Université Centre Val de Loire / ESCEM \\ 11, rue de l'Ancienne Comédie - Poitiers - 86001 Cedex - France \\ Tel: 33-(5)-4960-58 $00 \quad$ E-mail: dbretones@escem.fr
}

\author{
Carlos Scheel \\ EGADE Business School, ITESM \\ Ave. Fundadores y Rufino Tamayo \\ Valle Oriente, Garza García, NL, C.P. 66269, México
}

Tel: 52-(81)-8625-6191 E-mail: cscheel@itesm.mx

Received: July 20, 2011

Accepted: August 11, 2011

doi:10.5539/ibr.v4n4p3

\begin{abstract}
The development of high-tech clusters has been enhanced by the European authorities. In France a high-tech cluster policy was implemented in 2004 to establish competitiveness poles in the entire territory. Of the 71 clusters established, a few were built from existing industrial districts. That is the case of the Cosmetics Valley industrial district that was transformed into a high-tech cluster in 2005. The cluster readiness factors, known as the enabling conditions, and the supporting conditions are assessed, based on a methodology stemming from a worldwide cluster benchmark. The results obtained from a qualitative survey highlight the strong points of the Cosmetics Valley cluster in terms of branding, technological innovation and supplier networks. The limits to this clustering policy are indicated and possible evolution suggested.
\end{abstract}

Keywords: Clusters, Innovation, Strategy, Regional development, Meso economy

\section{Introduction}

French industry, like that of most Western economies, is facing enhanced relocations caused by low cost competition coming from the emerging countries. To counterbalance this trend the government authorities established a new national research and innovation framework, which included the CP initiative (competitiveness poles). This initiative relies on the setting up of competitive high-tech clusters, which provide companies with a sustainable competitive advantage on a worldwide basis. The policy focuses on innovation as the means to anticipate future business changes (Porter, 2000b; Romelaer, 1999).

Industrial districts have existed in France and Europe since the 18th century. They have been described by Marshall (1925) at the beginning of the 20th century and, in addition, have been analyzed in some parts of Europe. French industrial districts (established after World War II) called "Systèmes Productifs Locaux (SPL)" have been analyzed by Pecqueur (2001). The success of Italian districts has been demonstrated by Beccattini (1987) and Brusco (1982). Technological districts have been examined by Saxenian (1993) and Grossetti (2004). The cluster concept has been put forward by Porter (2000a). The CP initiative is an attempt to adapt the French economy to the pressure of globalization. This initiative also recognizes that technological change and human capital are endogenous and not exogenous to the growth process (Martin \& Sunley, 1998) and that clusters are an appropriate way to integrate these two key factors.

The need for the establishment of CPs relies upon a prospective work on the French innovation and research system which was conducted in the early 2000s. The conclusions were that academic research was insufficiently connected to research programs in major industrial groups, among many other factors (SFRI, 2007; La documentation Française, 2008). In addition, French SMEs showed very few working relations with either academic research or applied technical centers. The European Innovation Scoreboard shows that France did not feature among the leading group of European countries in terms of innovation (European Innovation Scoreboard, 2009).

\section{Competitiveness pole initiative}

The French cluster initiative, Pôles de Compétitivité, was implemented in the spring of 2004 and was defined by the Inter-ministerial Delegation for Land Planning and Competitiveness (DIACT) in 2005 as "the combination in a 
given geographic space of firms, training institutions and public or private research centers engaged in generating synergies to execute shared innovative projects". On the same track, the partnerships may be organized toward a market or a scientific and technological domain. The competitiveness poles have grown out of two concepts, the place inherited from the industrial district, and the innovative high-tech cluster (Aliouat, 2010). A national tender was issued in 2004 and, by the end of 2005, 67 clusters had been created (Cohen, 2007). This number rose to 71 clusters by early 2007 (Kierzenkowski, 2009). These clusters or CPs were covering all industrial fields, from agro business to manufacturing and service sectors, with a strong focus on R\&D and innovation. SMEs represented $70 \%$ of the companies involved in these clusters.

The survey conducted during the spring of 2008 by the French Business Confederation (MEDEF, 2008) to discover company points of view on the implementation of the initiative was sent to the $71 \mathrm{CPs}$. There was a response rate of $49 \%$, with 35 questionnaires sent back. Information was based on statistics, on the one hand, and text on the other, including spontaneous proposals. The methodology of this survey was based on the analysis of CPs companies according to their profile. The outcome of this survey indicates why members want to join the CPs and defines the main inhibitors to the clustering strategy. It also shows the possible improvements which have to be implemented (Bretones \& Scheel, 2011).

\section{Cosmetics Valley cluster assessment}

The authors have been assessing cluster readiness and the benefits of the CPs initiative in the Cosmetics Valley cluster. The method used relies upon the appraisal of the Cosmetics Valley's cluster enabling and supporting conditions. Each of these two subsets is assessed according to specific metrics; the enabling conditions (market conditions, regional attractiveness, industrial competitive enablers, business environment enablers) and the supporting conditions (infrastructural drivers, economic and financial enablers, public policy and legal enablers, social and cultural environments). Results are shown in a graphic format and allow formulation of possible improvements dealing with the Cosmetics Valley development scenarios.

\section{The Cosmetics Valley Cluster}

The Cosmetics Valley competitiveness pole promotes the development of the perfume and the cosmetics industries. The informal company networks existing prior to the Cosmetics Valley are shown. This industry represented a turnover of 16.3 billion $€$ in 2007 in France, of which over 50\% corresponds to exports. Different features of the Cosmetics Valley's revitalization, turning it into a high-tech cluster, are described and assessed. Currently, the Cosmetics Valley is clustering 229 companies with a turnover of 9 billion $€$. Of the Cosmetics Valley companies, 75\% are SMEs. With more than 10,000 jobs generated these SMEs represent 35\% of the total cluster employment .

\section{INSERT FIGURE I HERE.}

\subsection{The inception}

The origin of the Cosmetics Valley (Figure 2) dates back to the 1970s when the perfumer Fabergé made the decision to locate the company's R\&D teams and manufacturing plant near the city of Chartres in the Eure-et-Loir department (100 km from Paris) in 1975. This relocation was to be followed by others, such as Lancaster and Guerlain. This was understood by industrialists as a strong signal to decentralize companies located quite close to Paris. Most leading companies in the field of cosmetics and perfumery follow this example and establish their plants around Chartres or in the neighboring departments. An informal cosmetics network was being created, relying on the actors' reputation.

In the 1980s, the Eure-et-Loir department development agency (Codel) realized that additional development related to these cosmetics industries was possible. The Codel manager informed the local authorities and acted as a boundary spanner to promote the cosmetics industry (Ansel, 2005). Meanwhile, many SMEs were set up to provide the industrial groups located in this area with adequate services. The number of companies relocating in the area increased; however, contact among them was broadly informal. The local boundary spanner tried to apply new business practices he had learned a few years earlier in Italian industrial districts. He set up a cosmetics association in 1994 which facilitated cooperation among members. Informal relations were being transformed and institutionalized. This directly affected the companies' mutual relationships. The goal was also to enhance the bargaining power of the SMEs with the big industrial cosmetics groups.

\subsection{The industrial district era}

A leading personality of the industry accepted the position of president of the association in order to make it grow. New communication relying on the luxury industry was then promoted within France and in international cosmetics fairs. The reinforcement of links between members established a common identity process. In 2000, the association obtained the status of an SPL (French industrial districts) from government authorities, and it was baptized 
"Cosmetics Valley", name widely used in international fairs. At this stage of development, the Cosmetics Valley industrial district was concentrated in the "Eure-et-Loir" department. This branding strategy started to have an impact on Asian companies, such as Shiseido and Pacific Creation, which settled there to join the industrial district. Local authorities enhanced their support for the cosmetics district, which strengthened its institutional identity.

\subsection{The competitiveness pole status}

The restricted area of the Cosmetics Valley appeared nonetheless to be a limiting factor, as few big companies were established in the neighboring territories. Geographic extension was the next step to continue expanding and promoting the Cosmetics Valley. In addition, district orientation had been focusing mainly on the relations among members and had very little connection with training centers and academic research. The Cosmetics Valley participated in the call for national competitiveness projects in 2004 and was recognized as a competitiveness pole in 2005, as shown in Figures 2 and 3. By then it covered an extended geographical area which included three administrative regions and seven departments. In 2011 it brought together 229 companies (Figure 1) and 1000 scientists working in the field of cosmetics and related sciences. The CPs status allows the Cosmetics Valley to fund its innovative projects in specific local and national budgets. The industrial district focused mainly on industrial relations now aims to organize training programs. It also sets up tight links with academic research. The goal aimed at articulating competencies with research has been reached. This move from an industrial district to a competitiveness pole has been described (Ansel, 2005). The development of efficient relationships with the academic community is another challenge. For this purpose a Cosmetics Campus has being established including all the pole's university components. Six universities specialized in R\& D in the fields of cosmetics and perfumeries have been joining the Cosmetics Valley. The final goal for the Cosmetics Valley is to be described and known as a world resource center for the cosmetics industry. The four types of agents--lead firms, followers, subcontractors and infrastructures suppliers--are present in this Cosmetics Valley cluster (Albino \& al, 2005).

\section{INSERT Figures 2 \& 3 HERE}

\section{4. $R \&$ D project qualifying}

One the missions assigned to the pole is qualifying the many projects submitted for funding. Since 2006 a 100 million $€$ have been invested in $R \& D$ and 62 projects qualified by the pole assessment committee. Sixty four laboratories and 103 companies are engaged in those projects, the majority of which are collaborative. Organizationally, two or three partners are involved per project on average, with a maximum of eight partners per project. These projects demonstrate that the association between private companies and public organizations varies, as do partners configurations: private/ private or private/ public and public/public. The Metflac project depicted here illustrates the benefits created by the enhancement of relations between R\&D laboratories and companies.

\subsection{The technology leverage: A marriage between the latest plasma technology and the decorative arts}

The Metflac project is the result of a partnership between an innovative SME from Cosmetics Valley, "DB Technique", and GREMI (Groupe de recherches sur l'énergétique des milieux ionisés), a research laboratory at the University of Orléans specializing in plasma. DB Technique, located in Cosmetics Valley, is a specialist in high-class industrial marking on any medium, For almost 20 years, this SME has demonstrated its mastery of printing processes (screen printing, flexography, digital and transfer printing), providing unique solutions adapted to the needs of a demanding customer base. This base is made up of major cosmetics companies like Shiseido, Chanel, Dior and Guerlain, but also includes pharmaceutical and automotive companies.

On the face of it, there is no link between cosmetics and plasma. However, thanks to the Cosmetics Valley cluster, these two organizations have been able to work together since 2007 on an innovative project involving the metallization of glass bottles intended for use as perfume packaging by plasma spraying.

In partnership with GREMI, this SME has developed a spray process for metalizing complex glass bottle shapes destined for the major perfume brands. The company has filed a patent, as there is keen interest from the great names in the cosmetics industry. This project adds dynamism to the industrial applications already mastered by the company and is a new springboard for it. The company participates in the restructuring of the inter-firm networks and the carrying out of specific processes to govern the innovative process (Carbonara, 2004).

\subsubsection{From aesthetics to the adhesion of films on bottles}

In the field of cosmetics packaging, where innovation plays an essential role, plasma-deposited metallic films have many applications. Such is the case with the decoration of perfume bottles, where the search for new techniques is always of current interest. In this project, the feasibility of depositing decorative metallic layers on glass containers by plasma was studied. In addition to the aesthetic aspect linked to combining alloys of different metals, it was necessary to study the adhesion of these films to the substrate and also their durability in aggressive 
environments. For the purely decorative aspect, five colors and two shades were produced, ranging from various shades of silver to gold, via the orange color of copper. In some cases it was possible to achieve a semi-transparent deposition. Using masks, it was possible to achieve deposition effects, such as stripes, for example, on bottles. Extensive work was done to perfect the properties of these coatings in terms of their adhesion and wearing properties under conditions of use. A multi-stage protocol was arrived at, so that the metallic coatings would adhere well to glass. This alliance between high technology and aesthetics gives rise to a new dimension in glass bottles with the added commercial advantage of color and contour effects, which makes the bottles more attractive and alluring. This illustrates that industries with clustering dynamics show a high degree of local cooperation with suppliers and universities (Brenner, 2005).

\section{Cluster Readiness}

The creation of competitiveness poles demands two main pullers if decision and policy makers, entrepreneurs and businessmen are to be convinced that the idea is viable and will bring about an outstanding economic, social and environmental benefit for the region. The first puller is the cluster-readiness of the region. The second is the determination of the real benefits of the pole for all the regional stakeholders. The parameters for cluster readiness assessment have been extracted from multiple cases of clustering in different countries (Argentina, Colombia, Ecuador, Mexico, New Zealand, etc.) and several industries (leather, software, flower growing, health, textiles, food, construction, etc.) where the Compstrac $O$ Methodology has been used. Most parameters have been validated by experts in clustering strategies and by the application cases themselves. They are documented in the project reports and in the papers by: Scheel, C. \& Pineda, L., (2011), Scheel, C..\& Ross, C. (2007), Scheel, C.\& Gomez, G., (2007).

\subsection{C-Readiness}

Cluster readiness is the degree to which a community and its industrial sector are prepared to participate in world-class competitive arenas and to perform as an industrial cluster (not as individual companies, corporations or simple production chains). The main condition needed to incubate and sustain a cluster operation is the capacity to associate the valuable capabilities of its components, necessary to keep an emerging value generation among all the cluster affiliates.

What is measured here is the capacity for association, synchronicity and coordination (complementariness and commonality (Note 1)) of all core capabilities among producers of wealth and their complements, to work as a whole systemic unit in a well-connected networked world. Based on successful worldwide clusters, several case studies in the literature, and extensive experiences of the authors, eight categories have been defined that, in general, assess the clustering readiness of a region. The clustering factors are divided into two groups: a first set of basic conditions that must exist to have a world-class performing pole of competitiveness, and a second group of factors that are the enabling conditions that support the main drivers.

The primary enabling conditions are the following: market conditions necessary to induce cluster integration, regional attractiveness enablers, industrial competitiveness enablers, entrepreneurial productivity and business environment enablers. The supporting conditions include: structural drivers (connectivity, physical and technology infrastructure) for clustering stakeholders, economic conditions and financial enablers that support world-class clusters, public policy and legal enablers for effective clustering, and social and cultural environments that leverage the clustering process.

\section{INSERT TABLE 1 HERE.}

\subsection{Cosmetics industry international best practices}

The best practices in the cosmetics and perfume industry have been analyzed from a few industry surveys. This sector is fully international and major groups coming from the Triad (North America, Europe, and Asia) are competing for worldwide market shares.

\begin{tabular}{|c|c|}
\hline $\begin{array}{c}\text { Primary enabling } \\
\text { conditions }\end{array}$ & Best Practices of the Conditions that determine the Industry \\
\hline $\begin{array}{l}\text { Market conditions } \\
\text { necessary to induce } \\
\text { cluster integration }\end{array}$ & $\begin{array}{l}\text { o } \begin{array}{l}\text { The European personal products market generated total revenues of \$152.6 billion in 2009, } \\
\text { representing a compound annual growth rate (CAGR) of 3.3\% for the period spanning 2005-2009. }\end{array} \\
\text { The European personal products market has the presence of leading players like L'Oreal, Procter \& Gamble Company and } \\
\text { Johnson \& Johnson. Supermarkets and hypermarkets are the main buyers in many countries and generally exert strong buyer } \\
\text { power, especially if they are large chains. The fact that manufacturers of personal products are able to source some of their raw } \\
\text { material inputs from only a relatively small number of suppliers suggests that supplier power is boosted. The existence of some } \\
\text { strong brands and the scale economies associated with the necessary high-volume production facilities prevent the threat of new } \\
\text { entrants from becoming a significant factor. Rivalry is intensified by high fixed costs and exit barriers. } \\
\text { Despite the fact that the BRICs will continue to perform well, some countries are becoming saturated by major global brands } \\
\text { that already have a strong foothold in these regions. Up-and-coming so-called 'frontier markets' (term that describe the equity }\end{array}$ \\
\hline
\end{tabular}


markets of the smaller and less accessible, but still "investable", countries of the developing world) will be increasingly attractive for manufacturers looking to tap into as yet underdeveloped markets.

The breakdown of the world cosmetics and perfume market according to a L'Oréal estimate in 2007 shows the following ratios; skin care $(32 \%)$, make up $(17 \%)$, perfumes $(12 \%)$, hair products $(27 \%)$, toiletries $(12 \%)$.

The performance of the market is forecasted to decelerate, with an anticipated CAGR of $2.9 \%$ for the five-year period 2009-2014, which is expected to lead the market to a value of $\$ 176.1$ billion by the end of 2014 . Comparatively, the German and UK markets will grow with CAGRs of $1 \%$ and $2.8 \%$ respectively, over the same period, to reach respective values of $\$ 29.6$ billion and \$21.2 billion in 2014 .

\begin{tabular}{|c|c|}
\hline $\begin{array}{l}\text { Regional } \\
\text { attractiveness } \\
\text { enablers }\end{array}$ & $\begin{array}{l}\text { o The cosmetics segment recorded revenues of } \$ 22.6 \text { billion in FY2009, a decrease of } 0.6 \% \text { as compared } \\
\text { to } 2008 \text {. The decline in the revenues was primarily due to declining sales of the products in the Western } \\
\text { Europe, Latin America and Eastern Europe. } \\
\text { OTC healthcare is the largest segment of the personal products market in Europe, accounting for } 26.2 \% \\
\text { of the market's total value. } \\
\text { Germany continued to be the most lucrative cosmetics, toiletry and perfume market in Europe, with } \\
\text { value sales approaching } € 13 \text { billion. The market clocked another year of positive growth in } 2008 \text { with a } \\
2 \% \text { value increase from } 2007 \text {, and positive growth was seen across most categories. Rising disposable } \\
\text { income ensured positive performance for the overall market. } \\
\text { In 2008, the UK enjoyed one of the fastest growth rates among the five key European countries, with } \\
\text { cosmetics sales showing great resilience in the face of economic downturn. Growth of premium } \\
\text { products was a key driver of overall sales. } \\
\text { Fragrances saw the most impressive growth, increasing by } 11 \% \text { in } 2008 \text {. In line with the trend for } \\
\text { premium goods, fine fragrances performed best with double digit growth, helped by a number of } \\
\text { successful launches. } \\
\text { Scandinavian countries continued to post some of the strongest growth in Western Europe, despite the } \\
\text { maturity of cosmetics and toiletries. Decorative cosmetics were the best performing sector, going up by } \\
\text { 9.2\% in value terms in Denmark and } 6.1 \% \text { in Norway. Younger consumers are highly driven by the } \\
\text { latest fashion trends and always look for the latest emerging brand in decorative trends, including eye } \\
\text { make-up, where big eye lashes were the order of the day. } \\
\text { The new EU markets are Bulgaria, Cyprus, the Czech Republic, Estonia, Hungary, Latvia, Lithuania, } \\
\text { Malta, Poland, Romania, Slovakia and Slovenia. The largest market for cosmetics, toiletry and perfume } \\
\text { products was Poland. Sales in Poland were almost three times higher than Romania, the second largest } \\
\text { market, while the Czech Republic is in third place. }\end{array}$ \\
\hline $\begin{array}{l}\text { Industrial } \\
\text { competitiveness } \\
\text { enablers }\end{array}$ & $\begin{array}{l}\text { The European personal products market is highly fragmented, with three top players accounting for } 26.1 \% \text { of the total market } \\
\text { value. } \\
\text { Germany accounts for } 18.5 \% \text { of the European personal products market value. } \\
\text { L'Oreal is the leading player in the European personal products market, generating a } 10.5 \% \text { share of the market's value. } \\
\text { Procter \& Gamble Company accounts for a further } 10.4 \% \text { of the market. } \\
\text { The distribution strategy varies according to the perfume and cosmetics brand positioning, from exclusive distribution by } \\
\text { geographical territory to selective distribution and multi-channel distribution. } \\
\text { The existence of some strong brands and the scale economies associated with the necessary high-volume production facilities } \\
\text { prevent the threat of new entrants from becoming a significant factor. Rivalry is intensified by high fixed costs and exit barriers. } \\
\text { Branding is an important way of maintaining end-user loyalty and, as a result, retailers are required to stock the more popular } \\
\text { brands, which reduces their bargaining strength and buyer power. }\end{array}$ \\
\hline $\begin{array}{l}\text { Entrepreneurial } \\
\text { productivity and } \\
\text { business enablers }\end{array}$ & $\begin{array}{l}\text { With the exception of three groups (Estée Lauder, LVMH and Clarins), almost all of the leading perfume and cosmetics } \\
\text { companies act on the consumer segment. The margins generated by consumer products are indeed higher than those achieved } \\
\text { by premium care. In addition, professional luxury care and dermatological targets capture a narrower market and generate sales } \\
\text { volumes much smaller than consumer products. }\end{array}$ \\
\hline $\begin{array}{c}\text { Supportive enabling } \\
\text { conditions }\end{array}$ & Best Practices of the Conditions that determine the Industry \\
\hline $\begin{array}{l}\text { Structural drivers } \\
\text { (connectivity, } \\
\text { physical and } \\
\text { technology } \\
\text { infrastructures) for } \\
\text { clustering } \\
\text { stakeholders }\end{array}$ & $\begin{array}{l}\text { Operating in a context of slowing demand in mature markets (Western Europe, North America, and Japan), although } \\
\text { competition in some routes has increased in recent years. To counter them, the global fragrance and cosmetics groups have } \\
\text { expanded their distribution channels to other networks including dedicated circuits (L'Oreal, LVMH, Beiersdorf, etc.), } \\
\text { e-commerce (Shiseido, L'Oréal, Coty, etc.), operated stores (Natura, LVMH, Shiseido, etc.) or direct sales (Avon and Natura). } \\
\text { This diversification of marketing channels is more about the operators that are present on the high end because it allows them to } \\
\text { control the flow of their products and their brand. } \\
\text { Johnson \& Johnson's research facilities are located in the U.S., Belgium, Brazil, Canada, China, France, Germany, India, Japan, } \\
\text { the Netherlands, Singapore and the UK. The company and its subsidiaries operate } 147 \text { manufacturing facilities. } \\
\text { Pharmacies/drugstores form the leading distribution channel in the European personal products market, accounting for a 33.7\% } \\
\text { share of the total market's value. Supermarkets/ hypermarkets account for a further } 30.7 \% \text { of the market. }\end{array}$ \\
\hline
\end{tabular}




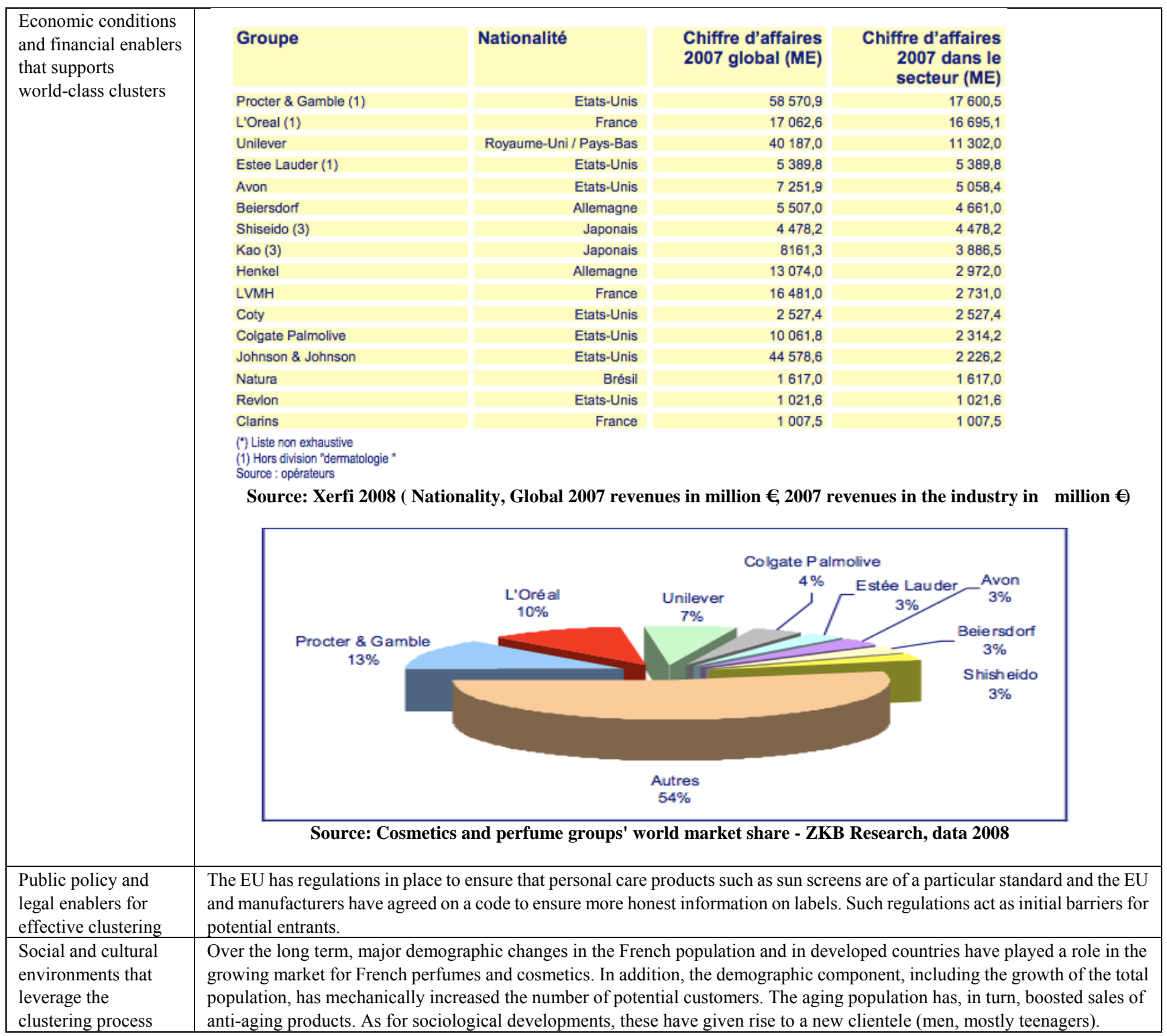

\section{Cosmetics Valley Cluster-Readiness}

\subsection{Qualitative survey}

In order to find if the region has the proper conditions to support the success of the cluster, a cluster readiness assessment has been developed, on the basis of a questionnaire integrating the primary enabling conditions and the supporting conditions (Scheel \& and Pineda, 2011). These conditions integrated, for each key factor (Table 1), the specific sub-factors listed. These sub factors number 48 in the extended questionnaire, was submitted to seven executives belonging to the cluster administration. The texts obtained from the interviews were crossed with published data and information on the Cosmetics Valley. The analysis that is presented focuses on the key conditions profiling the Cosmetics Valley. The scores obtained for the 48 variables have been positioned on a scale ranging from 0 to 10 (maximum).

\subsection{Primary enabling conditions}

The four primary macro-conditions described have to be fulfilled to promote a cluster's steady growth.

\subsubsection{Market conditions necessary to induce cluster integration}

The existence of both domestic and external markets in the region is a strong condition for most successful clusters. Access to a wide population and dynamic markets are clearly advantageous features of the cluster. The Cosmetics Valley production accounts for more than $70 \%$ of French industry exports and global market companies are present (Guerlain, L'Oréal, LVMH, Procter \& Gamble, Shiseïdo). These companies rely on a significant number of first-second-third-tier suppliers. The region outsources services in Asia for packaging and is sourcing raw materials 
in various parts of the world. The employees working in the Cosmetics Valley represent $25 \%$ of the French perfume and cosmetics industry jobs.

\section{INSERT FIGURE 4 HERE.}

From the information above we can observe that most indicators show that the market conditions are favorable for cluster implementation. There is global branding, with access to domestic and international markets, and the demand may be outsourced, which promotes the presence of multiple suppliers in the region. The only factor that may deflect the current market demand is bargaining power; many brands have a strong bargaining power, as shown in Figure 4. In general, the market favors the implementation of a successful clustering in the region.

\subsubsection{Regional attractiveness enablers}

This section of the survey assesses the region's capacity to attract important components of the industrial sector. Anchor companies are established in the region, which provides attractive capabilities for foreign direct investors from Asia, Europe and the United States. Establishment of the pole in 2005 made it possible to set up close relations with universities and $\mathrm{R} \& \mathrm{D}$ labs. New technology-based companies are emerging and regional and public investment programs have been qualified by the cluster. However, venture capital is not sufficiently developed and most young high-tech companies rely on regional or national subsidies coupled with classic bank loans to support their growth.

\section{INSERT FIGURE 5 HERE.}

The region has world-class players. It has the capacity for public and private funding for research and development, and there is an effective, although not officially established, regional innovation system to support the activities of the innovation chains. Nonetheless, the region has limited supporting linkages to support an associative culture, which must be improved to enhance the industrial sector supply chains. Also, the region must enhance its entrepreneurial programs as well as the business accelerators in order to promote new start-ups and the insertion of the local clusters into world-class production systems. In general, though, the region shows strong factors for becoming an attractive pole.

\subsubsection{Industrial competitive enablers}

Clusters can develop where the presence of key customers stimulates the development of effective industrial activities and competitive advantages among suppliers. The cosmetics cluster makes it easier to build alliances between complementary and supporting industries. The existing suppliers are linked to large corporations and show high productivity performance. There is an associative culture and alliances (inter- and intra-industry supply chains). The existing companies have technology enabling core competencies and world-class differentiators. There is a high rate of new products versus current ones. Products show mass customization and / or production in small lot sizes. These existing companies have to compete to maintain a worldwide reputation.

\subsubsection{Entrepreneurial productivity and business environment enablers}

Successful clusters will have many individuals with entrepreneurial spirit who are flexible and willing to try new ideas. They exploit new opportunities or technologies, bring innovation to the market place or take significant calculated risks. In the Cosmetics Valley leaders take responsibility for collective competitiveness by improving their business process structures. There is strong competition at the regional level and in R\&D programs, some sponsored by governmental institutions. The number of innovations is increasing and is enhanced by the existing Regional Innovation System (RIS). The RIS anticipates an improved organization of the available competencies in the Cosmetics Valley. Skills would be positioned in specialized resource centers located throughout the area: ingredients, formulation, sensory aspects, olfaction, logistics, packaging and retailing.

\subsection{Supporting conditions}

The groups of factors enabling conditions that support the main drivers of the basic clustering drivers are described.

\subsubsection{Infrastructural drivers}

The structural drivers are split into two large areas: soft (or smart) infrastructures, such as intelligence systems, software capabilities, knowledge-based systems, etc.; and hardware infrastructures, such as communication links and physical facilities.

Some firms linked to the clusters are able to build research consortia, like Coty, the world's largest fragrance company, or Puig, the Spanish Catalan leader in perfumes and cosmetics. The cluster affiliates benefit from access to modern transportation hubs either by road or railway, or by ship with Le Havre harbor. A number of potential suppliers (first- second- and third-tier ones) are located within a $100 \mathrm{~km}$ radius. The cluster's affiliates receive specific market, economic and competitive intelligence from the Cosmetics Valley services. They are informed 
about possible technology transfers. Universities are expanding incubators to nurture existing and future start-ups. The inter-firm network promoted internal relations at the expense of external involvement and constitutes the structural "embeddedness" (Simsek \& al 2003) of the clustering infrastructure.

\section{INSERT FIGURE 6 HERE.}

From the reported data, it can be observed that the region provides appropriate infrastructure to support the clustering strategy. In general, most factors need very little to become world-class drivers. Linked to the other enabling factors, the assembling of strong innovation chains (ideas from research centers to new start-ups) and value networks is a strategy that must be implemented to achieve a strong soft (smart) and physical infrastructure that can support the success of this industry in the region.

\subsubsection{Economic and financial enablers}

Revenues generated by the Cosmetics Valley affiliates ( 9 billion $€$ ) represent $56 \%$ of the national perfume and cosmetics industry revenues (16 billion $€$ ). Banks, such as the "Caisse d'Epargne (savings bank)" or the HSBC group, participate in the financing of SMEs. Venture capitalists are beginning to show interest in some of the Cosmetics Valley start-ups. The cosmetics pole attracts foreign direct investment from Europe, the United States and Asia. High risk investments in fundamental R\& D projects are funded via dedicated governmental entities in the field of stem cell research or nanotechnologies.

\subsubsection{Public policy and legal enablers}

Cluster structures require special public policies, legal frameworks and government strategies to support coordination, commonality of goals and clear rules of association among all stakeholders. Local, regional and national government policies aligned to a common goal are required. In the Cosmetics Valley the rules for investment are clear and there are national government policies supporting the industrial strategies. Oligopolies exist in the industry, but the national anti-trust authorities have been imposing fines on them in accordance with the European administration. Access to specific funds is granted to companies willing to assemble genuine, successful cluster structures. The incentive policies to enhance technology transfer from universities and technology centers (public and private) exist, but need to be fostered. They participate in the recombination of local systems to generate or gain access to new capabilities in local development (Longhi, 2005). An improved alignment between government levels (departments, regional and national) and the communities located in the Cosmetics Valley would enhance the leverage created by these enablers.

\subsubsection{Social and cultural environments}

The cultural attitudes and practices in the clustering location are an important issue to be considered for achieving sustainable development. In the Cosmetics Valley there is a collective vision through the cluster branding and its presence in international fairs. There is also a culture of industrial association and alliance through the established suppliers' chains. Connections with the academic entities are recent, however, and need to be fostered.

\section{INSERT FIG 7 HERE.}

In general, the enabling conditions (markets, attractiveness, competitiveness, productivity) and the supporting activities (infrastructure, economic and financial drivers, government policies and social and cultural environments) in the region are favorable for backing the success of the Cosmetics Valley.

\section{Conclusions}

The Cosmetics Valley brand is promoted at international fairs and this contributes to a common, shared vision among the affiliates. The Cosmetics Valley cluster has been able to attract foreign direct investment and set up what is called (Pecqueur 2001) a meso-economy encompassing three administrative regions. In this meso- economy approach, the economic space constitutes "the analysis of the building dynamics of an inside compared to an outside (external to the cluster)". This new territorial knowledge management emphasizes the concept of networking and relies upon the concepts of interactive learning and knowledge creation (Cappelin, 2003).

The cluster alignment process distinguishes three integrated layers; the intra-organizational layer and other institutions, the internal organization layer of projects and programs bringing together "value chain" organizational players and the layer of industrial and market clusters (Molina \& al 2001). The existing alignment should be enhanced to provide superior leverage. Anchor companies from the Triad are attractive for many SMEs as suppliers' or partners in the clusters' projects. The existing supply chains are being reinforced with the extended Cosmetics Valley competitiveness pole that integrates three administrative regions. In the future these measures might improve the Cosmetics Valley global market share in the industry. The orientation towards specialized resource centers should promote a better evaluation of the skilled labor force. The Cosmetics Valley development shows the establishment of an informal association in the 1980s which has become an industrial district in the 2000s' and now 
displays some of the features characterizing high-tech clusters. The orientation towards globalization is likely to improve the Cosmetics Valley's performance in the long term. Considering the enabling factors to support the clustering strategies, we believe the region has the cluster-readiness to develop a successful high- tech cosmetics industry.

\section{References}

Albino, V., Carbonara, N. \& Giannoccaro, I. (2005). Industrial districts as complex adaptative systems: Agent based models of emergent phenomena. In C. Karlsson, B. Johansson \& R.R. Stough (Eds.), Industrial cluster and Inter-Firm Networks (pp. 58-82). United Kingdom: Edward Elgar Publishing, Inc.

Aliouat, B. (2010). Les pôles de compétitivité: Gouvernance et performance des réseaux d'innovation. France: Hermès Science publications.

Amin, N. \& Thrift, N. (1994). Living in the global. In N. Amin \& N. Thrift (Eds.), Globalization, institutions, and regional development in Europe (pp. 1-19) Oxford, UK: Oxford University Press.

Amin, A. \& Cohendet P. (2004). Architectures of Knowledge: Firms, Capabilities and Communities. Oxford: Oxford University Press.

Ansel, JL. (2005). La Cosmetic Valley du système productif au pôle de compétitivité. Vie et Sciences EconomiquesAndese, 170, 89-95. Retrieved from: http://www.andese.org/revue-vse-170-171-les-poles-de-competitivite-du-laboratoire-au-marche/110-la-comestic-val ley-du-systeme-productif-local-au-pole-de-competitivite.html

Beccattini, G. (1987), Mercato e forze locali: Il distreto industriale. Bologna: Il mulino

Benaroya, F. (2005). Le point sur les délocalisations. In. L. Fontagné \& J.H. Lorenzi, Désindustrialisation, délocalisation, Rapport du Conseil d'analyse Economique (pp. 147-163). Paris: La Documentation française.

Brenner, T. (2005). Innovation and Cooperation during the Emergence of Local Industrial Clusters: An empirical study in Germany. European Planning Studies, 13(6), 921-938. DOI:10.1080/09654310500188522, http://dx.doi.org/10.1080/09654310500188522

Breschi, S. (2000). The Geography of Innovation: A cross-sector analysis, Regional Studies, 34(3), 213-229. Retrieved from: http://didattica.unibocconi.it/mypage/upload/48944_20101220_021841_BRESCHI00.PDF

Bretonès, D. \& Scheel, C. (2011). Fostering innovation the role of french competitiveness poles: Critical analysis for an application in the Latin American countries. Journal of Global Business Administration, 3, 1-18. Retrieved from: http://ww.jgba.org/index.php/jgba/article/viewArticle/89

Brusco, S. (1982). The Emilian model: Productive decentralization and social integration. The Cambridge Journal of Economics, 6(2), 167-184. Retrieved from: http://cje.oxfordjournals.org/content/6/2/167.full.pdf

Cappelin, R. (2003). Territorial Knowledge Management: Towards a metrics of the cognitive dimension of agglomeration. International Journal of Technology Management, 26(2/3/4), 303-325. DOI:10.1504/IJTM.2003.003384, http://dx.doi.org/10.1504/IJTM.2003.003384

Carbonara, N. (2004). Innovation processes within geographical clusters: a cognitive approach. Technovation, 24, 17-28. DOI:10.1016/S0166-4972(02)00046-9, http://dx.doi.org/10.1016/S0166-4972(02)00046-9

Cohen, E. (2007). Industrial Policies in France: The old and new. Journal of Industrial Competitiveness Trade, 7(3-4), 213-227. DOI:10.1007/s10842-007-0024-8, http://dx.doi.org/10.1007/s10842-007-0024-8

DIACT. (2008). Evaluation des pôles de compétitivité: Synthèse du rapport d'évaluation, [www document] http://www.diact.gouv.fr

European Innovation Scoreboard, (2009), [www http://www.proinno-europe.eu/page/european-innovation-scoreboard-2009

GREMI (2011). Groupe de recherches sur l'énergétique des milieux ionisés, Université d'Orléans. Retrieved from http://www.tech-orleans.fr/orleans_val_de_loire-fr-idm-97-guide_innovation-20.html

Grossetti, M. (2004). Concentration d'entreprises et innovation: Esquisse d'une typologie des systems productifs locaux. Géographie Economique Société, 6, 163-167. DOI:10.3166/ges.6.163-177, http://dx.doi.org/10.3166/ges.6.163-177

Kierzenkowski, R. (2009). The Challenge of Restoring French Competitiveness. OECD Economics Department Working Papers,720, OECD publishing, (C) OECD. Doi:10.1787/222054166088, http://dx.doi.org/10.1787/222054166088 
La documentation Française. (2008). la politique des pôles de compétitivité, 2005-2008, ISBN: 978-2-11007398-3, http://www.ladocumentationfrancaise.fr/catalogue/9782110073983/

Longhi, C. (2005). Local systems and networks in the globalization process. In Quadrio, A. \& Fortis, M. (Ed.), Research and technological innovation: The challenge for a new Europe (pp. 81-108). Heidelberg: Physica Verlag.

Marshall, A. (1925). Principles of Economics. 8th edition. London: MacMillan.

Martin, R., \& Sunley, P. (1998). Slow convergence? The new endogenous growth theory and regional development. Economic Geography, $74 \quad$ (3), 201-227. $\quad$ DOI:10.1111/j.1944-8287.1998.tb00113.x, http://dx.doi.org/10.1111/j.1944-8287.1998.tb00113.x

Molina, A. H., \& Kinder, T. (2001). National systems of innovations, industrial clusters and constituency building in Scotland's electronics industry. International Journal of Entrepreneurship and Innovation Management, 1 (2), 241-275. DOI:10.1504/IJEIM.2001.000456, http://dx.doi.org/10.1504/IJEIM.2001.000456

Pecqueur, B. (2001). Gouvernance et régulation: un retour sur la nature du territoire. Géographie, Economie, Société, 3(2), 229-245, ISSN (printed): 1295-926X ; Digital ISSN: 1958-5802

Pecqueur, B (2007). Le tournant territorial de la globalisation. In Itçaina,X., Palard, J. \& Segas, S. (Ed.), Régimes territoriaux et développement économique (pp. 261-277). Rennes: Presses Universitaires de Rennes. ISBN: 978-2-7535-0381-6; http://www.pur-editions.fr/couvertures/1222864004 doc.pdf

Pôles de compétitivité, [www document) http://competitivite.gouv.fr/documents/commun/Les_Poles_en_mouvement/Poles_de_competitivite-nationaux/table aux-bord-statistiques/Cosmetic_Valley_1948.pdf

Porter, M. (2000a). Locations, clusters and company strategies, In Clark, G., Feldman, M., \& Gertler, M. (Ed.), The Oxford Handbook of Economic Geography (pp. 253-274). Oxford: Oxford University Press.

Porter, M. (2000b). Location, competition and economic development: local clusters in a global economy. Economic Development Quarterly, 14, 15-35. DOI:10.1177/089124240001400105, http://dx.doi.org/10.1177/089124240001400105

Potter, J., Miranda, G., Local Economic and Employment Development (Program), Organization for Economic Co-operation and Development. \& Source OECD (Online service). (2009). Clusters, innovation and entrepreneurship. Paris: OECD. ISBN: 978926404442-5 (Print); 9789264044326 (PDF). DOI:10.1787/ 9789264044326, http://dx.doi.org/10.1787/9789264044326-en

Romelaer, P. (1999). Relations externes des entreprises et gestion des innovations. In. Foray D. \& Mairesse, J. (Ed.), Innovations et performances (pp. 385-398). Paris: Ecole des Hautes études en sciences sociales.

Saxenian, A. (1993). Regional advantage: culture and competition in Silicon Valley and Route 128. Cambridge: Harvard University Press.

Scheel, C. \& Pineda, L. (2011). Building industrial clusters in Latin America: Paddling upstream. International Journal of Socio-technology and Knowledge, 3, 34-54. DOI:10.4018/jskd.2011010102, http://dx.doi.org/10.4018/jskd.2011010102

Scheel, C. \& Ross, C. (October, 2007). Strategies for building successful industrial clusters in Latin America. In the conference of XLII Annual CLADEA Meeting: The College of Business Administration at Florida International University.

Scheel, C. \& Gomez, G. (October, 2007). Why the Latin American region has not succeeded in building world-class industrial clusters. Proccedings of KGCM 2007 11st World Multi-Conference on Systemics and Informatics, USA, 3, 278-283. ISBN: 978-1-934272-17-6, 278-283

SFRI. (2007). Quel avenir pour le système français de recherche et d'innovation? ANRT, [www document]. Retrieved from: http://www.anrt.asso.fr/imgAdmin/1212673669547.pdf

Simsek, Z., Lubatkin, M. \& Floyd S.W. (2003). Inter-firm Networks and Entrepreneurial Behavior: A structural embeddedness perspective. Journal of Management, 29 (3), 427-442. DOI:10.1016/S0149-2063_03_00018-7, http://dx.doi.org/10.1016/S0149-2063_03_00018-7

\section{Notes}

Note 1. M. Porter uses these two terms as key factors for assembling a cluster. 
Table 1. Clustering readiness conditions surveyed (Scheel, C. \& Bretonès, D. 2011)

\begin{tabular}{|cl|}
\hline A & Primary enabling conditions \\
\hline 1 & Market conditions ( 6 items) \\
\hline 2 & Regional attractiveness enablers (8 items) \\
\hline 3 & Industrial competitive enablers (6 items) \\
\hline 4 & Entrepreneurial productivity and business enablers (4 items) \\
\hline B & Supporting conditions \\
\hline 5 & Infrastructural drivers ( 9 items) \\
\hline 6 & Economic and financial enablers (6 items) \\
\hline 7 & Public policy and legal enablers (5 items) \\
\hline 8 & Social and cultural environments (4 items) \\
\hline
\end{tabular}

Affiliates' growth

\section{Cosmetic Valley 2005 - 2011}
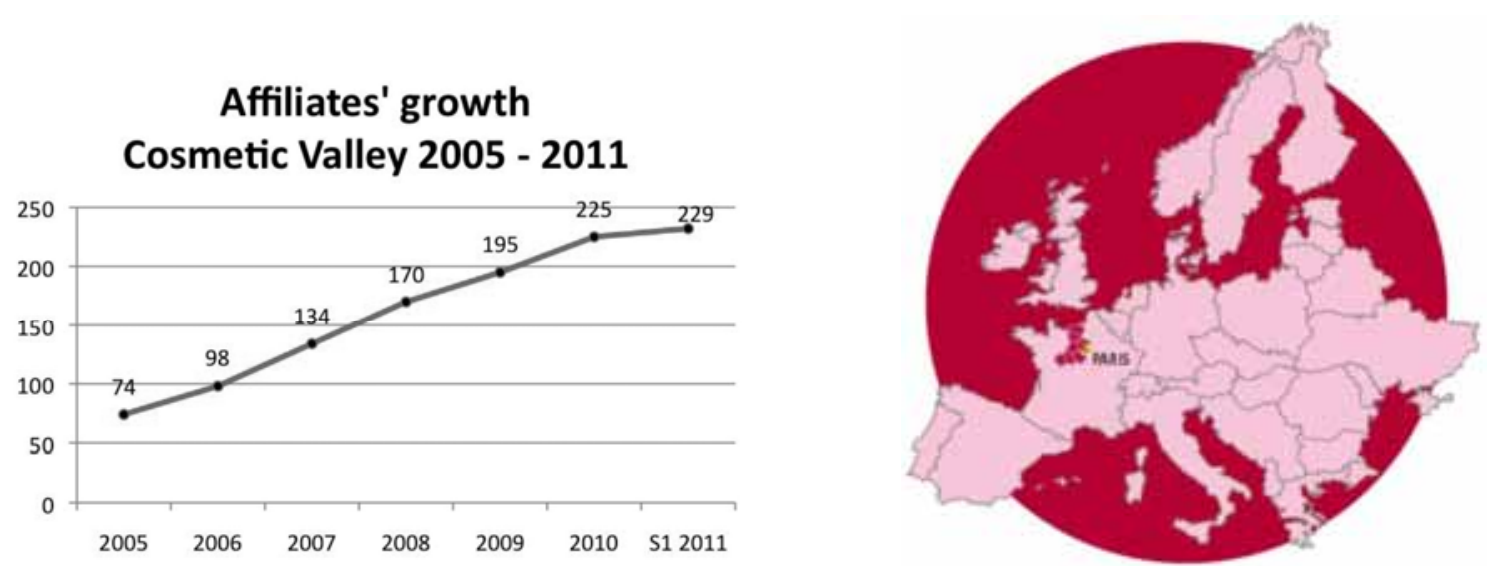

Figure 1. Growth of Cosmetics Valley affiliates

Figure 2. The Cosmetics Valley in Europe

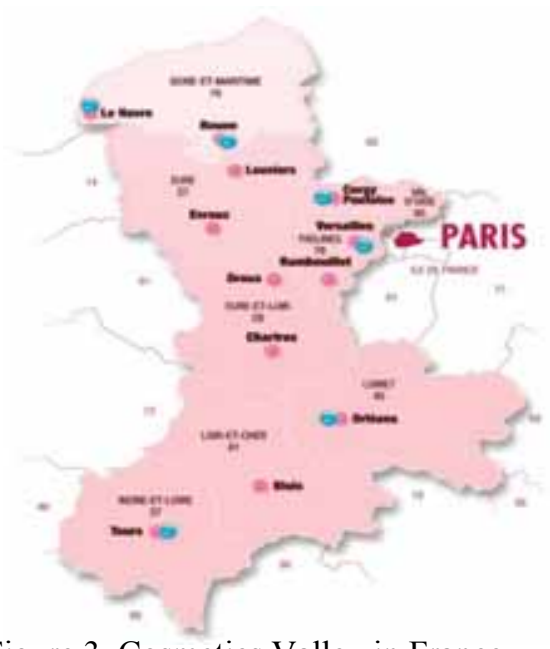

Figure 3. Cosmetics Valley in France

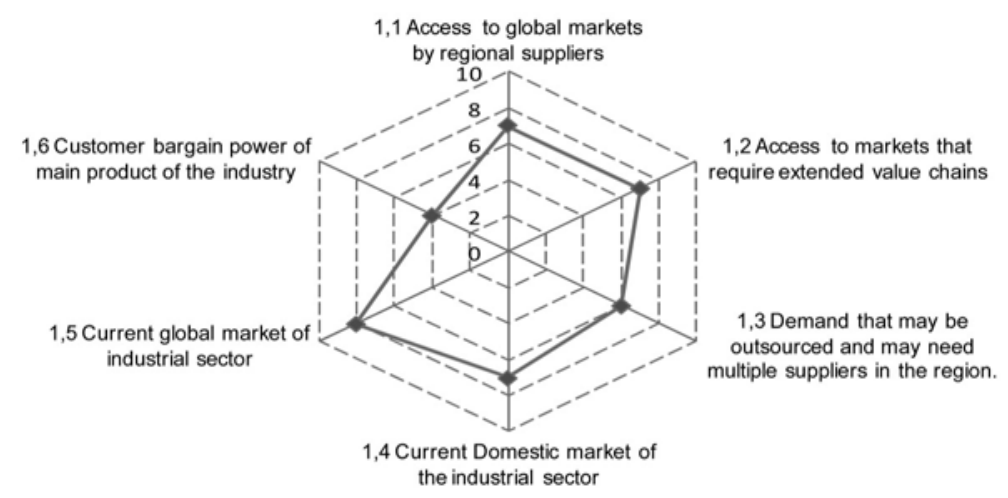

Figure 4. Market conditions 


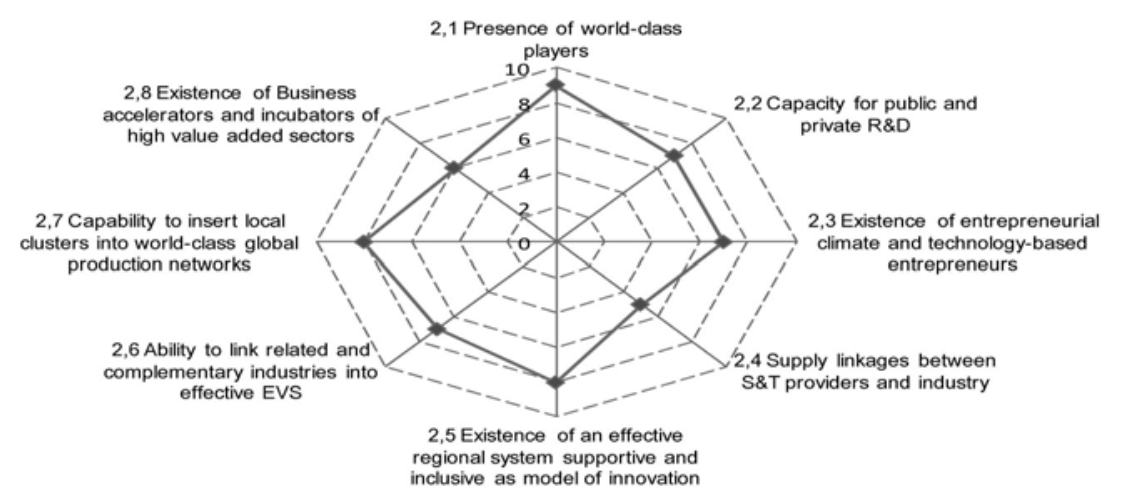

Figure 5. Regional attractiveness

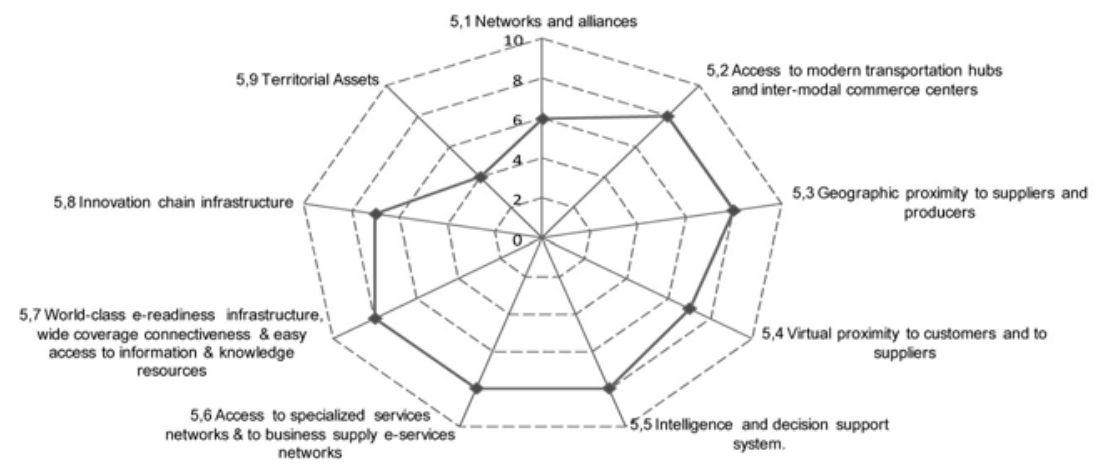

Figure 6. Infrastructural drivers

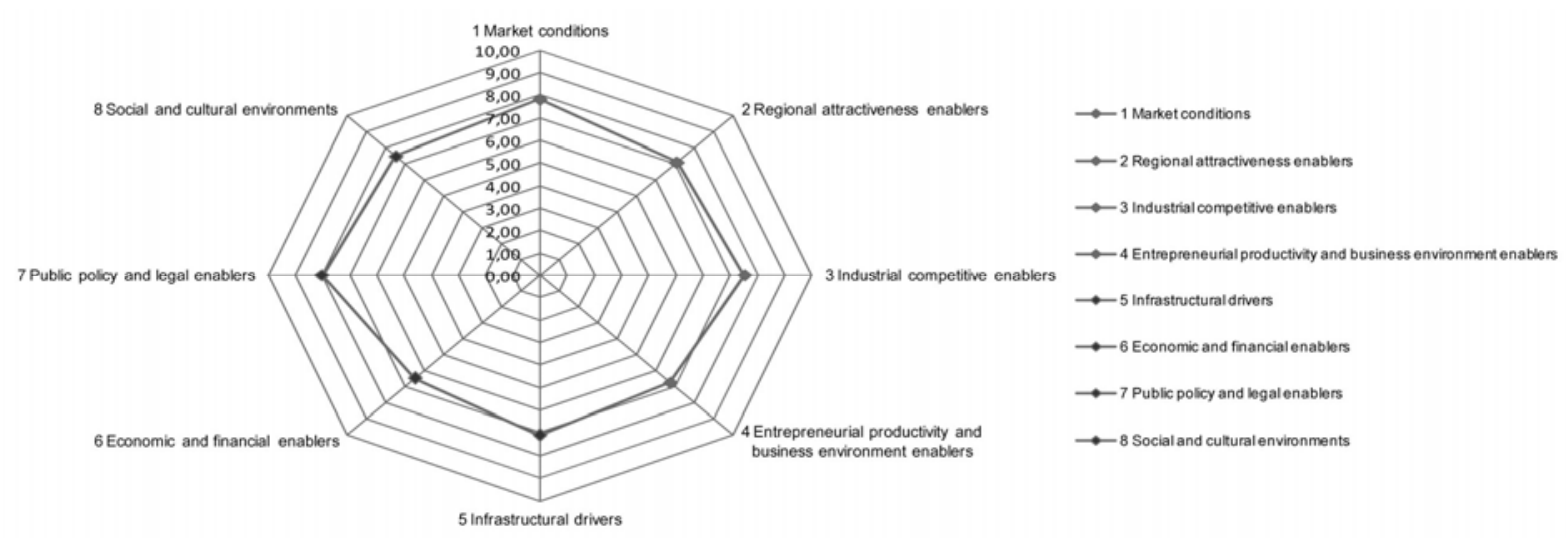

Figure 7. Overview of enabling and supporting factors 